\title{
Devonian-Carboniferous slivers within the basement area of north-east Oscar II Land, Spitsbergen
}

\author{
Yoshihide Ohta, Claude Lepvrier \& \\ Friedhelm Thiedig
}

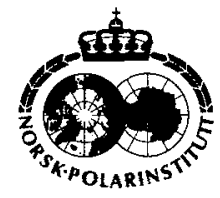

Formed during an early compressional period in the opening of North Atlantic Ocean, a Tertiary fold-thrust belt extends along the mid-tosouthern part of the western coast of Spitsbergen. Complex thrust structures involve the basement (Caledonian and older) and many shallow dipping thrust faults dissect the overlying cover rocks (Devonian and younger) in Oscar II Land in the northern part of the belt. Some of these faults occur within the basement rocks with slivers or fault blocks of the cover rocks from south-western Brøggerhalvøya to innermost St. Jonsfjorden in north-eastern Oscar II Land. Six of the slivers contain Carboniferous rocks and one is a fault-bounded block with Devonian rocks. These steeply west-dipping faults form a complex fault system EOFC (Engelskbukta-Osbornbreen Fault Complex) - within the basement area. The lithological units of the basement are separated by faults within the EOFC, which is structurally continuous with the Brøggerhalvøya fold-thrust zone to the north and is thought to continue to the foldthrust zone on the south-eastern coast of St. Jonsfjorden. Some previous authors considered that the two lithologically contrasting Vendian diamictites and intervening Moefjellet Formation are stratigraphically continuous and defined two separate tilloid successions in the present area. This interpretation has been extended over the whole of western Spitsbergen. However, the present study indicates that these two tilloid formations and the Moefjellet Formation are separated by the faults, probably thrusts, within the EOFC and are not in a continuous stratigraphic relation. Therefore, the two-stage history of Vendian glaciation seems questionable.

Y. Ohta. Norwegian Polar Institute, clo NGU, Box 5348 Majorstua, N-0304 Oslo, Norway; C. Lepvrier, Tectonic Laboraton;, ESA 7072, P. and M. Curie University, 4 Place Jussieu, 75252 Paris Cedex O5, France; F. Thiedig, Institute of Geology and Palaeontology. University of Münster, Corrensstrasse 24, D-48149 Münster. Germany.

Several thin- and thick-skinned fold-thrust zones develop along the west coast of Spitsbergen, the largest island of Svalbard Archipelago (Fig. 1). This belt was caused by the Tertiary diastrophism related to the early plate movement of the opening of the North Atlantic Ocean, and is generally referred to as the West Spitsbergen Fold-Thrust Belt. The trend of the belt turns from a NNW to a north-west direction, from inner St. Jonsfjorden to Brøggerhalvøya (Brøgger peninsula) in Oscar II Land. A complex thrust structure of Carboniferous-Tertiary sediments is developed in the peninsula, involving metamorphic rocks of the basement (Orvin 1934; Challinor 1967; Hjelle \& Lauritzen 1982; Dallmann, Andersen et al. 1993; Saalmann et al. 1997). The faults between the 


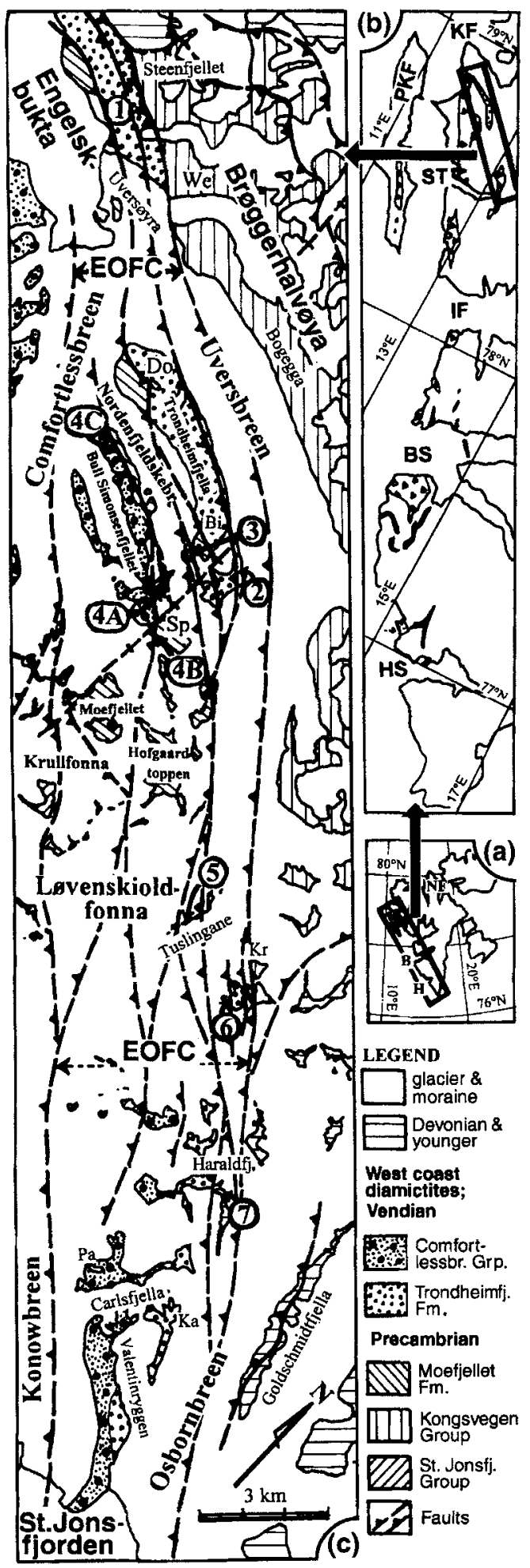

basement and the cover sediments (Devonian to Tertiary) follow the same trends as the belt. Some thrusts - at least two - displacing the cover sediments in Brøggerhalvøya seem to extend southward, bounding different lithological units of the basement (Fig. 1).

Since the 1960s, several localities of Carboniferous and Devonian rocks have been recognized in north-eastern Oscar II Land (Harland, Horsfield et al. 1979; Hjelle, Ohta et al. 1979; Winsnes \& Ohta 1988; Dallmann, Andersen et al. 1993), as narrow slivers and a block along the faults probably thrusts - within the basement area. Many previously unpublished field observations were incorporated in the tectonic map of Dallmann, Andersen et al. (1993).

In the lithostratigraphy of the Vendian tilloid successions in Oscar II Land, Waddams (1983) and Harland, Hambrey et al. (1993) identified two tilloid successions separated by a thick marble (Fig. 1). These authors claimed that primary stratigraphic contacts exist in this area.

This article describes the occurrences of Carboniferous and Devonian rocks within the basement area of north-eastern Oscar II Land as presently known and suggest their structural significances both for the Tertiary tectonics as well as the stratigraphy of the Vendian tilloids in a general geological view. No detailed kinematics will be presented since the data are limited due to the difficult accessibility of the localities.

\section{Description of the localities}

Seven localities of Devonian and Carboniferous

Fig. 1. (a) The Svalbard Archipelago. Place name abbreviations are: $\mathrm{B}=$ Bellsund; $\mathrm{H}=$ Hornsund: $\mathrm{NF}=\mathrm{Ny}$ Friesland. Rectangle indicates area enlarged in (b). (b) Distribution of west coast diamictites along the south-western coast of Spitsbergen: $\mathrm{KF}=$ Kongsfjorden; $\mathrm{ST}=\mathrm{St}$. Jonsfjorden; PKF $=$ Prins Karls Forland: IF = Isfjorden: $\mathbf{B S}=$ Bellsund; HS: Hornsund; triangles = upper tilloids of Harland, Hambrey et al. (1993); dotted $=$ lower tilloids of Harland, Hambrey et al.; black = lower tilloids of Harland, Hambrey et al., but the Grenvillian unconformity conglomerates in our interpretation. Rectangle indicates area enlarged in (c). (c) Geological map of eastern Oscar II Land, showing the localities of described occurrences of Devonian and Carboniferous rocks. EOFC $=$ EngelskbuktaOsbornbreen Fault Complex; We $=$ Welderyggen: $\mathrm{Do}=$ Domkyrkja; $\mathrm{Bi}=$ Bispesetet; $\mathrm{Sp}=$ Spannklumpen: $\mathrm{Kr}=$ Kregnes toppen; $\mathrm{Pa}=$ Patronen; $\mathrm{Ka}=$ Kausen: circled numbers $1-7$ are localities described in this paper. 
rocks found as a fault block and narrow slivers are described below, from south-western Brøggerhalvøya to north-eastern St. Jonsfjorden (Fig. Ic).

\section{Locality 1 . North of Uversфyra}

A thin sliver, 5-10 $\mathrm{m}$ wide. of white sandstones with thin coal beds, presumed to belong to the Lower Carboniferous Orustdalen Formation and a grey massive limestone with siliceous concretions, presumed to be a part of the Upper Carboniferous Scheteligfjellet Formation (Cutbill \& Challinor 1965; Harland 1997), occurs on the south-western slope, ca. $100 \mathrm{~m}$ asl, of Welderyggen and the southern slope of Steenfjellet. The rocks are distributed along the fault-bounding micaceous schists of the Bogegga Formation of the Kongsvegen Group (Orvin 1934) in the north and the non-tillitic sandy phyllites of the Trondheimfjella Formation (Waddams 1983) in the south (Table 1). The sliver is discontinuous along the fault which extends south-eastward under the moraine of Uversøyra and Uversbreen. The north-western extention continues to one of the thrust-displacing Carboniferous strata in Brøggerhalvøya.

The marginal fault planes of the Carboniferous sliver are covered by scree, but their trend is estimated to be ca. $300-310^{\circ}$ with steep to vertical dips. Schistosities in marbles, schists and phyllites of the basement dip mainly $60-90^{\circ} \mathrm{W}$ and SW and strike 135-180, oblique to the boundary trend, while the beddings in the Carboniferous sediments within the sliver show $10-15^{\circ} \mathrm{W}$ dips (Fig. 2). Subsidiary faults in the marbles near the boundary fault bear oblique normal striae plunging northwest, suggesting a late extensional event already documented in Brøggerhalvøya (Lepvrier \& Geyssant 1984; Lepvrier 1992; Saalmann \& Brommer 1997; Saalmann et al. 1997).

About $2 \mathrm{~km}$ north-west of Locality 1, red clastic beds with dolomites of the Brøgertinden Formation occur along the fault. The bedding of these rocks has subparallel strikes with steep dips to the south-west.

\section{Locality 2. South-eastern edge of Trondheimfjella}

Trondheimfjella is the type locality of the Vendian tilloids, the Trondheimfjella Formation (Harland, Horsfield et al. 1979; Harland, Hambrey et al. 1993: Waddams 1983). Definitive tillite occurs on the north-eastern slope of Trondheimfjella, while siliceous phyllites, areno-argillaceous and calcareous phyllites dominate structurally above and below. The rocks in the middle ridge and northeastern slopes are separated by a south-westdipping steep fault which, north-east of Uversøyra, extends toward the north-west.

At the south-eastern corner of Trondheimfjella, a ca. $100 \mathrm{~m}$ thick sliver of Carboniferous sediments occurs in the foothill of the reverse fault which is the southern extension of the fault mentioned above, though the eastern boundary of the sliver is under a glacier. The rocks are red sandstones and poorly sorted conglomerates, with thin layers of coarse-grained sandstone, locally with a dolomitic matrix. A few thin limestone beds occur in the upper stratigraphic part of the

Table 1. Stratigraphic scheme of eastern Oscar II Land, Spitsbergen. (The author is aware that this interpretation differs from that presented in the map by Hjelle. Piepjohn et al. 1999.)

\begin{tabular}{|c|c|c|}
\hline $\begin{array}{l}\text { Middle } \\
\text { Carboniferous }\end{array}$ & $\begin{array}{l}\text { Gipshuken Group } \\
\text { Scheteligfjellet Fm.: limestones, sandstones } \\
\text { Brøggertinden Fm.: conglomerates, sandstones }\end{array}$ & \\
\hline $\begin{array}{l}\text { Lower } \\
\text { Carboniferous }\end{array}$ & $\begin{array}{l}\text { Billefjorden Group } \\
\text { Orustdalen Fm.: sandstones, conglomerates, coal seams }\end{array}$ & \\
\hline Devonian & Red Bay Group: red breccia and conglomerates & \\
\hline Vendian & $\begin{array}{l}\text { Comfortlessbreen Group } \\
\text { tilloids, phyllites. quartzites. green phyllites } \\
\text { Trondheimfjella Fm.: tilloids. phyllites, carbonates }\end{array}$ & \\
\hline Neoproterozoic & Moefjellet Fm.: carbonates & \\
\hline Mesoproterozoic & $\begin{array}{l}\text { Kongsvegen Group } \\
\text { Nielsentj. Fm.: phyllites, carbonates } \\
\text { Steenfj. Fm.: carbonates } \\
\text { Bogegga Fm.: schists, gneisses }\end{array}$ & $\begin{array}{l}\text { St. Jonstjorden Group } \\
\text { phyllites, carbonates. } \\
\text { quartzites, greenschists }\end{array}$ \\
\hline
\end{tabular}




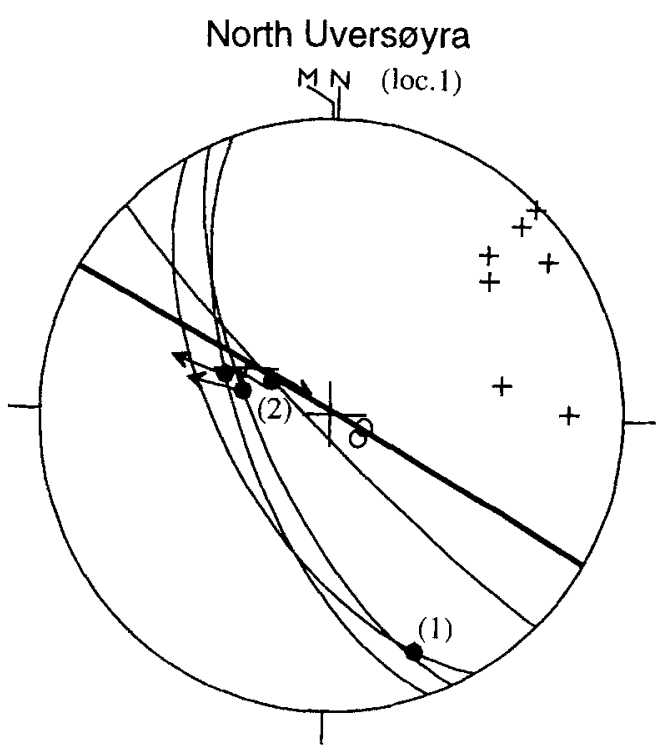

Fig. 2. Stereographic projections of the measured structures from Locality 1. Lower hemisphere projections on equal area stereonet. Heavy line = estimated marginal fault; thin lines $=$ subsidiary faults; dots $=$ fault stria, arrows indicate movement direction. (1) and (2) refer to the movement episodes measured on the same fault place: small open circles = pole to bedding; $\operatorname{cros} s=$ pole to cleavage.

succession. These lithologies are correlated with part of the Billefjorden Group and possibly with the Brøggertinden and Scheteligfjellet Formations (Table 1).

The Carboniferous beds have roughly northsouth strikes with nearly vertical dips, though two measurements have gentle dips, and are younging eastwards (Fig. 3). Poles to bedding concentrate along a great circle, which suggest a fold with a subhorizontal axis. Bedding and the boundary fault are subparallel and this may suggest an orthogonal compression structure prior to, or during, the faulting. The possibility of different stages of folding and faulting cannot be excluded.

The boundary fault along the west side of the Carboniferous sliver strikes roughly north-south and has a steep westerly to vertical dip, locally with steeply south-plunging slip striations. A subsidiary fault with a moderate south-east dip also has a moderate south-south-east plunging slip striae, showing normal and dextral fault movement components. Two other subordinate faults strike nearly perpendicular to the boundary fault with a normal slip. The successive normal fault movements are consistent with each other and corre- spond to a later phase of extension similar to that observed at Locality 1 (Fig. 2).

\section{Locality 3. South-western Trondheimfjella}

Several subvertical, westerly dipping steep faults bound sandy-shaly phyllites with thin marble layers of the Trondheimfjella Formation against thick marbles of the structurally overlying Moefjellet Formation around the westernmost peak, Domkyrkja of Trondheimfjella. Since stratigraphically lower marbles in the west overlie the tillitic phyllites in the east, the fault zone is considered to be a thrust zone. This thrust zone passes Bispersetet in the southern part of Trondheimfjella, where it incorporates slivers of Carboniferous rocks.

A thin, brecciated, grey limestone with a trace of a coal seams occurs at the pass between the peaks $830 \mathrm{~m}$ in the west and $810 \mathrm{~m}$ in the southeast in Bispersetet. These may be correlated with the Scheteligfjellet Formation. The fault zone extends with a ca. $330^{\circ}$ strike and subvertical to steep westerly dips (Fig. 4), though the fault itself is covered by scree, and passes through the pass between the $830 \mathrm{~m}$ and $860 \mathrm{~m}$ peaks in the northwest. Beddings in the Carboniferous limestone strike mainly WNW-ESE with steep south-west dips. This obliquity may be explained by a dextral

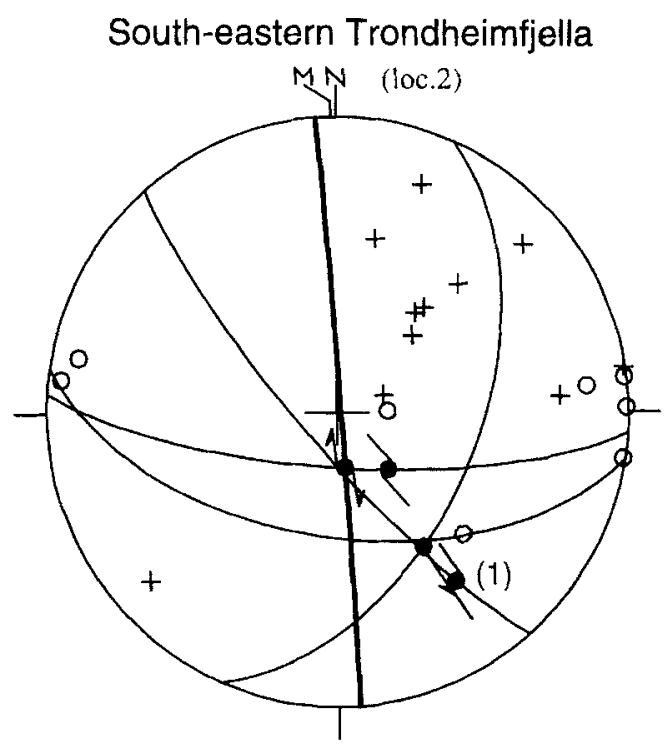

Fig. 3. Stereographic projections of the measured structures from Locality 2 . Thick line $=$ observed reverse fault; legend otherwise the same as for Fig. 2. 


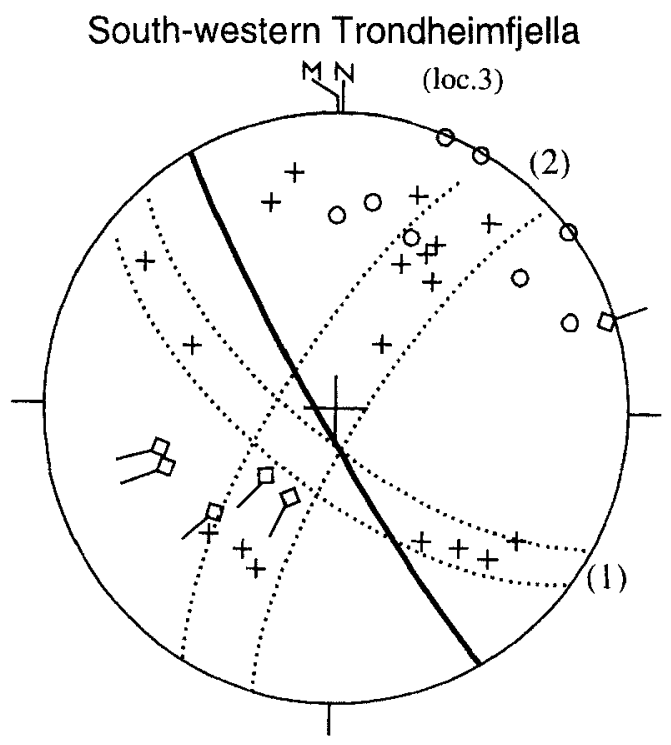

Fig. 4. Stereographic projections of measured structures from Locality 3. For legend see Fig. 2. Additional: small squares with short lines = axes of crenulation and mesoscopic folds in the phyllitic rocks. For explanations of (1) and (2), refer to the text.

transpression, or by a rotation during supposed thrusting, though the possibility of different stages of formation of the fold and fault cannot be excluded.

Two folds with axes of different direction are inferred from the great circles of phyllitic cleavages: 1) one fold with a gentle north-eastplunging axis; and 2) one with a gentle south-eastplunging axis. No overprinting relationship, which could signify a polyphase folding. has been identified, except for a young episode of crenulation formation.

The western slope of the $830 \mathrm{~m}$ peak is composed of a wide scree of white sandstones, possibly Billefjorden Group, but without solid exposure. The rocks seen in the scree are similar to those across a glacier to the south at Locality $4 \mathrm{~A}$. ca. $500 \mathrm{~m}$ perpendicular to the strike, but their relation is unknown due to ice cover.

\section{Locality 4A. Small ridge extending to the north in south-east Bull Simonsenfjellet}

This narrow ridge consists of white sandstones and conglomerates with thin coal seams and plant fragments in coarse-grained sandstones. which can be correlated with the Orustdalen Formation of the Billefjorden Group. A narrow fault-bounded phyllite zone occurs between the Carboniferous rocks (Fig. 5d).

The southern boundary fault is not exposed, but its south-east extension is observed at Locality $4 \mathrm{~B}$, having a strike in $140^{\circ}$ and steep westerly to vertical dips (Fig. 5b). To the south of the fault are sandy siliceous phyllites with strong cleavages of north-south to north-west-south-east strikes and about $5-10^{\circ} \mathrm{W}$ dips. The rocks are typical tillites around $4 \mathrm{~B}$, containing subangular dolomite and quartzites clasts, less than $15 \mathrm{~cm}$ in size, scattered in a coarse-grained, phyllitic sandstone matrix. The northern border is under a glacier.

The Carboniferous rocks in the upper part of the locality are gritty sandstones, containing very thin seams of coal, and conglomerates with round quartzite clasts, less than $5 \mathrm{~cm}$ across, having north-west-south-east strikes and 70-80 NE dips. Cross-bedding observations show that the beds are inverted.

The narrow sliver of basement rocks in the middle of the ridge is bounded by roughly 130 $135^{\circ}$ striking steep faults, subparallel to the southern boundary fault, with shallow south-eastplunging striations with slip direction indicating a dextral oblique slip movement (Fig, 5a). The rocks are quartzitic phyllites, sandy, grey-black phyllites with or without garnet, and brown dolostones, a total of ca. $50 \mathrm{~m}$ in width. Their cleavage has north-south to NNE-SSW strikes and moderate to gentle easterly dips. Mesoscopic fold axes trend ENE with moderate plunges and crenulation axes in a south-west trend with gentle plunges. The cleavages of the basement rocks in the south and middle of the Carboniferous rocks together may form a rough great circle around inferred NNESSW horizontal axis, subperpendicular to the Carboniferous structure, which does not confirm with the observed mesoscopic fold axes. This inferred fold may represent a post-Caledonian structure.

The Carboniferous rocks in the lower part of the locality are white sandstones and conglomerates with some plant fragments. The cross beddings show that the beds are in stratigraphically normal position. They have a similar bedding trend to the Carboniferous rocks in the upper part.

Two sets of NNE-SSW-striking, conjugated or pseudo-conjugated normal faults with steep to moderate east or west dips, occur within the Carboniferous rocks (Fig. 5a).

The bedding orientations of the Carboniferous rocks, inverted in the upper and upright position in 

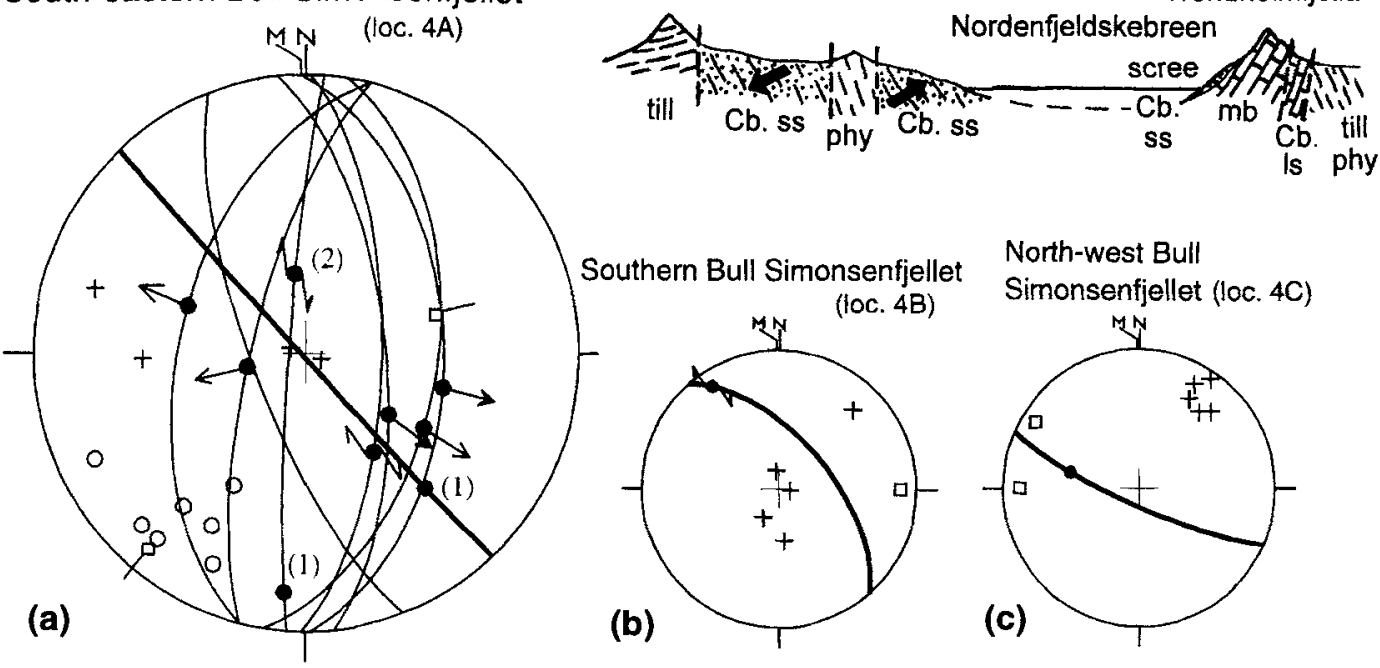

North-west Bull

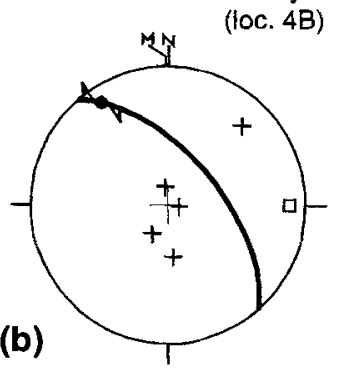

Simonsenfjellet (loc. 4C)

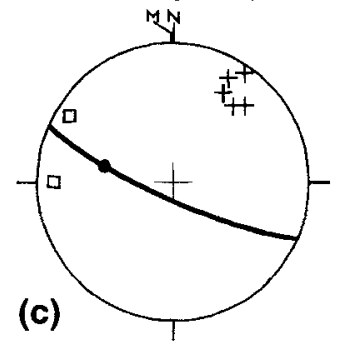

Fig. 5. Stereographic projections of (a) south-east Bull Simonsenfjellet, Locality 4A, (b) southern Bull Simonsenfjellet, Locality 4B, and (c) north-west Bull Simonsenfjellet, Locality $4 \mathrm{C}$, as well as (d) schematic profile of the northern ridge. For legend see Figs. 2 and 4. In (d), dark arrows = stratigraphic younging directions; $\mathrm{Cb}=$ Carboniferous; $s \mathrm{~s}=$ sandstone; $\mathrm{ls}=$ limestone; $\mathrm{mb}=$ marbles; phy $=$ phyllite; till $=$ tilloids.

the lower parts, indicate an overturned fold with a north-west subhorizontal axis. It can be speculated that this fold was formed by a synthetic compressional structure of an assumed dextral oblique, conjugated faults mentioned above, but it may also be older than the faulting: a thrust-related deformation.

\section{Locality 4B. Southern Bull Simonsenfjellet}

The southern boundary fault of Locality 4A extends to the south-east and passes a pass west of Spannklumpen, having $140^{\circ}$ trend with a steep north-east dip (Fig. 5b). There it separates the thick banded marbles of the Moefjellet Formation, which form Spannklumpen to the east, from a tillitic phyllite to the west. The marbles have north-west-south-east strikes and $60-70^{\circ} \mathrm{SW}$ dips, while the tillitic phyllites have east-west strikes and $0-30^{\circ}$ dips. A scree of white sandstones of the Carboniferous occurs along the fault on the south-western slope of Spannklumpen, but no bedrock exposure has been seen.

\section{Locality 4C. North-west Bull Simonsenfjellet}

The southern boundary fault of Locality 4A extends to the north-west along the northern slope of Bull Simonsenfjellet. This fault separates a ca. $100 \mathrm{~m}$ thick marble of the Moefjellet Formation in the north-east from phyllitic Vendian tilloids in the south-west on the northern ridge. The boundary between the banded schistose marbles and phyllites does not always show evidence of displacement around this locality, but local slickenside with moderately plunging slip striation has been observed at a few exposures (Fig. $5 c$ ).

The banded marbles to the north of the boundary are commonly brecciated at the contact to the phyllites and are locally stained yellow-brown by sulphide mineralization. On some profiles of local ridges branching to the north-east, the general structure of the banded marbles and the phyllites is slightly oblique across the boundary; therefore a fault is inferred. The quartzites and sandstones, ca. $2.2 \mathrm{~m}$ in total thickness, along the boundary could be of Carboniferous age, but this is difficult to judge due to their strong shearing.

These observations do not clearly confirm a fault at this locally, since displacement might possibly be accommodated along cleavage planes of the phyllitic rocks, but some dislocation along the boundary between the banded marbles and tillitic phyllites can be inferred, since the inferred fault is the northern extension of faults at Localities 4A and 4B. 


\section{Locality 5. Southem Tuslingane}

The northern half of the Tuslingane nunataks are composed of phyllitic tilloids that extend from Trondheimfjella southwards. The cleavages are with NNW-SSE strikes and moderate west dips. A distinct banded marble, 10-15 m thick, occurs in the middle part. Black phyllites occur to the south of the marble and they have cleavages emphasized by the black, shiny surface of the bituminous material, with north-west-south-east strikes and moderate south-west dips and gentle west-plunging mesoscopic fold axes. Such an extremely graphitic cleavage has not been seen in the basement rocks. Therefore, these rocks are thought to be derived from coal-bearing Carboniferous rocks.

An east-west-striking vertical fault separates the bituminous phyllites in the middle of the nunataks from a grey limestone, ca. $20 \mathrm{~m}$ thick, in the south. The bedding of the limestone has a north-west strike and a moderate south-west dip. Sandstones and thin shale beds occur further south of the nunataks. Fossils of plant fragments indicate the sandstones belong to the Billefjorden Group and the limestone to the Scheteligfjellet Formation. No observation on shear sence in the faults has been obtained.

A $3-4 \mathrm{~m}$ thick dolerite dyke, probably of Mesozoic, occurs in the north-eastern part of the nunataks.

\section{Locality 6. Kregnestoppen}

The eastern half of this high nunatak consists of thick dark grey, crystalline dolostones, partly sandy, of the Steenfjella Formation of the Kongsvegen Group (Orvin 1934). Near the top, a vertical, north-west-south-east-striking fault separates the dolostones from tillitic phyllites to the west. The tillitic phyllites have north-west-southeast strikes and moderate south-west dips and contain quartzite and thin schistose marble lenses.

A massive grey limestone, locally brecciated and siliceous with a brown colour. occurs on the lower part of the western slope, bounded by a north-south-striking, steep west-dipping fault. Fault striae are horizontal and reveal sinistral displacement, shown by the slip direction of the striae. Within the limestone, another fault with a similar attitude bears normal dip-slip striations. This limestone unit is presumed, though no critical supporting evidence has been found, to belong to the Carboniferous Scheteligfjellet Formation, since it lacks schistosity and has a fine-grained texture.

The westernmost part comprises strongly crenulated, biotite-bearing sandy phyllites with scattered quartzitic clasts, having cleavages of WSWESE strikes and moderate south dips. A small isolated nunatak further to the west consists of sandstone scree, possibly of the Billefjorden Group. but no solid exposure has been seen.

\section{Locality 7. South-east Haraldfjellet}

A steep ridge to the south-east into Osbornebreen is entirely composed of red-coloured, poorlysorted conglomerates. Angular clasts are quartzites and carbonates of various colours with a clastsupported texture; the matrix is red-coloured sandstone. Plant fragments, similar to those found by Gjelsvik (1974) on Lovénøyane in inner Kongsfjorden, were found at this locality (T. S. Winsnes, pers. comm. 1994), and indicate a Devonian age for these rocks. Bedding does not develop well and has $80-70^{\circ}$ strikes. Measured dips are mostly $20-30^{\circ} \mathrm{SE}$, but vary. A NNWstriking subvertical fault marks the western limit. but a local unconformity has been observed (H. D. Maher Ir., pers. comm. 1994). The eastern boundary is situated under a glacier.

A tilloid with a calcareous sandy matrix and thin marble lenses comprises the western part of the nunatak. The cleavages of rocks have north-westsouth-east strike and a moderate west dip. Dolostone layers are intercalated in the western ridge and NNE-SSW-trending breccia zones with sulphide mineralization developed in the westernmost nunataks. A dolerite dyke of $1 \mathrm{~m}$ thickness, probably Mesozoic, occurs with an east-west strike. The tillitic phyllites further west commonly contain quartzite layers.

\section{Discussion}

\section{Definition of the EOFC fault complex}

All Devonian and Carboniferous rocks described above occur along faults in a zone that extends from south-western Brøggerhalvøya to inner St. Jonsfjorden. The zone shows a very gently curved distribution from a north-west-south-west to a NNW-SSE strike.

The north-eastern boundary of the zone, includ- 
ing faults with the Carboniferous slivers at Localities 1 and 6 (Fig. 1), separates the Kongsvegen Group to the north-east from the tilloid-bearing phyllitic and carbonate successions to the west. Locality 7 is located on the southern extension of this fault. The Devonian rocks at Locality 7 seem to overlie the tillitic phyllites; though this is not confirmed on the outcrops, at least there are no micaceous schists similar to those of the Kongsvegen Group in the moraine blocks along the eastern foothill of the nunatak. Thus, the eastern boundary fault is located to the east of Locality 7 , and therefore this locality is included in the fault zone.

The south-western boundary of the fault zone is the connection of the westernmost localities of the Carboniferous slivers in Bull Simonsenfjellet, at Localities $4 \mathrm{~A}, 4 \mathrm{~B}$ and $4 \mathrm{C}$, but the southern part is located around the distribution boundary between the Moefjellet marbles plus tillitic phyllites in the east and the Mesoproterozoic St. Jonsfjorden Group to the west.

It seems possible to consider all the faults described above as belonging to a $3-5 \mathrm{~km}$ wide basement fault complex, the Engelskbukta-Osbornebreen Fault Complex (EOFC in Fig. 1c). This fault complex contain several subparallel faults, bounding various lithological units of the Vendian tilloids and distinctive marbles of the Moefjellet Formation, both Neoproterozoic, and separates these rocks from high-grade metamorphic rocks of the Kongsvegen Group to the northeast and from the St. Jonsfjorden Group to the south-west of the EOFC; both are considered to be Mesoproterozoic. The slivers of Carboniferous rocks and a block of Devonian rocks are distributed along the faults within the EOFC. The connection of the faults within the EOFC as illustrated in Fig. Ic is highly speculative, due to complexity within the fault complex and small occurrences separated by large glaciers.

\section{Linkage of the fault complex}

To the north-west of the EOFC, a multiple thrust complex, involving both basement and postDevonian sediments, is developed in Brøggerhalvøya (Orvin 1934; Challinor 1967; Manby 1988; Saalmann \& Blommer 1997; Saalmann et al. 1997). The north-western parts of two faults of EOFC are directly continuous with the faults of the Brøggerhalvøya thrust complex. Since most other faults within the EOFC have similar general nature, they are also considered to be thrusts. This suggests that the Carboniferous slivers occurring along the faults of EOFC are parts of the Carboniferous sediments that were deeply buried into the basement by an as yet unknown mechanism, most likely caught into thrusts (Saalmann 1999; Piepjohn et al. in press). Kinematics of fault movement are suggested at some localities, but the information is fragmented and no systematic interpretation can be made at the present stage.

A well developed fold-thrust zone is developed in the south-eastern coast of St. Jonsfjorden around Vegardfjella and Wittenburgfjella (Winsnes \& Ohta 1988; Welbon \& Maher 1992). The Carboniferous rocks of this area are underlain by a basement of low grade, tillite-bearing Neoproterozoic rocks, while to the west is the St. Jonsfjorden Group. Accordingly, this zone can be considered the southern extension of EOFC, which is underlain by the Neoproterozoic basement, while the exposing structural level is shallower in the south than that in the north of St. Jonsfjorden.

It is therefore proposed that the EOFC represents a deep structure of the Tertiary fold-thrust belt, developed along the basement and cover boundary zone in western Spitsbergen. The present observations are not enough to corroborate this hypothesis and detailed kinematic of polyphase deformation history as previously studied in other parts of the fold-thrust belt (Challinor 1967; Lepvrier \& Geyssant 1984; Lepvrier 1988, 1992; Manby 1988; Gabrielsen et al. 1992; Dallmann, Andersen et al. 1993; Braathen \& Bergh 1995; Maher et al. 1997).

\section{Lithostratigraphy of the Vendian tilloids}

Latest Proterozoic tilloids in Svalbard provide an important geological record of Vendian glaciation (Fig. 1b). Harland, Hambrey et al. (1993) interpreted the field relationships between the Comfortlessbreen Group. Trondheimfjella and Moefjellet Formations in Oscar II Land as stratigraphically conformable. Referring to the two stages of Vendian glaciation known in $\mathrm{Ny}$ Friesland (north-east Spitsbergen), Finnmark (northernmost Norway) and eastern Greenland, they considered that the Trondheimfjella Formation and the Comfortlessbreen Group can be correlated to the lower and upper tillite successions, respectively. These two have different lithologies in Oscar II Land. The lower succession is characterized by 
intercalations of many carbonate layers and has mainly calcareous sandy matrices, while the upper one contains many quartzite layers and clasts of granitic rocks (Waddams 1983; Harland, Hambrey et al. 1993).

The idea of two tilloid successions separated by a marble succession has been applied by Harland (1978) and Harland, Hambrey et al. (1993) to interpret the diamictites in west-central and southwestern Spitsbergen along a ca. $250 \mathrm{~km}$ long basement belt (Fig. 1b). All lower "diamictites" in the belt. e.g. the Konglomeratfjellet conglomerates in the south of Bellsund (Dallmann, Hjelle et al. 1990) and the Slyngfjellet conglomerates northern coast of Hornsund (Birkenmajer 1992; Ohta \& Dallmann 1998), have been correlated with the Trondheimfjella Formation. Thick marble successions above these diamictites in Chamberlindalen in the south of Bellsund and the Höferpynten marbles in Hornsund have been compared with the Moefjellet Formation, which has been placed between two tilloid successions. But these carbonate successions have been also correlated with the Akademikerbreen Group of Ny Friesland (e.g. Birkenmajer 1992), and the Akademikerbreen carbonates contain pre-Vendian microfossils in Ny Friesland (Knoll et al. 1989).

Our field observations in north-eastern Oscar II Land show that the two tilloid successions, the Trondheimfjellet Formation and the Comfortlessbreen Group, and the Moefjellet Formation in between, are separated by faults which involve Carboniferous slivers. These three formations do not show any primary stratigraphic relation, except for the Carlsfjella area, and are completely dismembered by faults, while the lithology of the two tilloid successions is contrasting. Harland. Hambrey et al. (1993) stated that clasts of granitic rocks are restricted to the Comfortlessbreen Group, but such clasts were also found in the Trondheimfjella Formation, on the southern slope of Bjørvikfjellet.

Carlsfjella, located to the south-west of Locality 7 in the southernmost EOFC, north-east of St. Jonsfjorden (Fig. 1c), consists entirely of tilloids and various phyllites. The tilloid succession includes several thin marble layers in the middle part of Haraldfjellet (west of Locality 7) and Kausen. while it is interbedded with many quartzite beds in the western part from Patronen to Valentinryggen, without any observable structural discontinuity. The marble-bearing lithology in the east is similar to the Trondheimfjella
Formation and that with quartzites in the west is identical to the Comfortlessbreen Group. There is no thick marble succession similar to the Moefjellet Formation between the two lithologically different tilloid successions. This is the only locality in the basement terrain of western Spitsbergen where two contrasting lithologies of Vendian tilloids occur without any structural break and with primary stratigraphic relations. Therefore, there is no evidence of two tilloid successions separated by a thick marble in Oscar II Land; accordingly, the application of the idea of two successions of Vendian tilloids, separated by a period of carbonate deposition, to the whole of western Spitsbergen (Harland, Hambrey et al. 1993) is questionable.

Existence of two lithologically contrasting tilloid-bearing successions is acceptable and all observable tilloids in western Spitsbergen may show one thick unit including both of these lithologies. Accordingly, all tilloid successions in western Spitsbergen have been informally called the west-coast Diamictite unit in recently published maps (Dallmann, Hjelle et al. 1990; Dallmann, Andersen et al. 1993; Ohta \& Dallmann 1998). If this is the case, western Spitsbergen has a different depositional history than north-eastern Svalbard and other regions such as northern Scandinavia and eastern Greenland, and might represent an exotic terrane juxtaposed during the Caledonian orogeny.

Acknowledgements. - Much unpublished information has been shared by T. S. Winsnes and A. Hjelle (Norwegian Polar Institute) and E. Tveten (Norwegian Geological Survey). Comments from, and discussion with, Dr. H. D. Maher Jr. are much appreciated. Part of the financial support was given by the French-Norwegian Science Cooperation Program. Prof. M. Bjørnerud kindly improved the language of this paper.

\section{References}

Braathen, A. \& Bergh, S. 1995: Kinematics of Tertiary deformation in the basement-involved fold-thrust complex, western Nordenskiöld Land, Svalbard: tectonic implications based on fault-slip data analysis. Tectonophysics 249. 1-29.

Birkenmajer. K. 1992: Precambrian succession at Hornsund. south Spitsbergen: a lithostratigraphic guide. Studia Geol. Pol. 98, 6-66.

Challinor, A. 1967: The structure of Brøggerhalvoya, Spitsbergen. Geol. Mag. 104, 322-336.

Dallmann, W. K., Andersen. A., Bergh, S. Maher, H. D., Jr. \& Ohta. Y. 1993: Tentiary fold-and-thrust belt of Spitsbergen, Svalhard. Nor. Polarinst. Medd. 128.

Datlmann. W. K., Hjelle, A., Ohta. Y., Salvigsen, O.. Bjornerud, 
M. G., Hauser. E. C., Maher, H. D., Jr. \& Craddock, C. 1990: Geological map of Sialbard 1:100,000, BI/G, Van Keulenfjorden. Nor. Polarinst. Temakart 15.

Gabrielsen, R. H., Kløvjan, O. S., Haugsb $\emptyset_{1}$ H., Midbøe, P. S., Nøttvedt. A., Rasmussen, E. \& Skott, P. H. 1992: A structural outline of the Forlandsundet Graben. Prins Karls Forland, Svalbard. Nor. Geol. Tidsskr. 72, 105-120.

Gjelsvik, T. 1974: A new occurrence of Devonian rocks in Spitsbergen. Nor. Polarinst. Årbok 1972, 23-28.

Harland. W. B. 1978: A reconsideration of Late Precambrian stratigraphy of southern Spitsbergen. Polarforschung 48.4461 .

Harland, W. B. 1997: The geology of Svalbard. Geol. Soc. Memoir 17. London: Geological Society of London.

Harland. W. B., Hambrey. M. J. \& Waddams, P. 1993: The Vendian geology of Svalbard. Nor. Polarinst. Skr. 193.

Harland, W. B., Horsfield, W. T., Manby, G. M. \& Morris, A. P. 1979: An outline pre-Carboniferous stratigraphy of central western Spitsbergen. Nor. Polarinst. Skr. 167, 119-144.

Hjelle, A. \& Lauritzen, $\emptyset$. 1982: Geological map of Svalbard 1:500,000, 3G, Spitsbergen northern part. Nor. Polarinst. Skr. $154 \mathrm{C}$

Hjelle, A., Ohta, Y. \& Winsnes, T. S. 1979: Hecla Hoek rocks of Oscar II Land and Prins Karls Forland, Svalbard. Nor. Polarinst. Skr. 167. 145-169.

Hjelle, A., Piepjohn, K., Saalmann, K., Ohta, Y., Salvigsen, O., Thiedig. F. \& Dallmann, W. K. 1999: Geological map of Svalbard 1:100,000, A7G, Kongsfjorden. Nor. Polarinst. Temakart 30.

Knoll, A. H., Swett, K. \& Burkhardt, E. 1989: Paleoenvironmental distribution of microfossils and stromatolites in the upper Proterozoic Backlundtoppen Formation, Spitsbergen. Ball. Geol. Soc. Am. 95. 1293-1302.

Lepvrier. C. 1988: Relais compressifs et distensits entre décrochements dans la chaîne tertiaire du Spitzberg (Svalbard. Norvège). (Compressional and extensional relay zones along the west Spitsbergen strike-slip belt [Svalbard, Norway].) Comptes Rendus Académie Sciences, tome 307, série II. 409-414.

Lepvrier, C. 1992: Early Tertiary paleostress distribution on Spitsbergen: implications for the tectonic development of the western fold-and-thrust belt. Nor. Geol. Tidsskr. 72, 129-135.

Lepvrier, C. \& Geyssant. J. 1984: Tectonique cassante et champs de contrainte tertiaires le long de la marge en coulissement du Spitsberg. Corrélations avec les mécanismes d'ouverture de la mer de Norvège-Groënland. (Brittle tectonics and Teriary palaeostress field along the Spitsbergen strike-slip margin. Correlations with the opening of the Norwegian-Greenland Sea.) Annales Société Geologique du Nord CIII, 333-344.

Maher. H. D., Jr.. Bergh, S., Braathen, A. \& Ohta, Y. 1997: Svartfjella, Eidembukta, and Daudmannsodden lineament Tertiary orogen-parallel motion in the crystalline hinterland of Spitsbergen's fold-thrust belt. Tectonics 16(1), 88-106.

Manby, G. M. 1988: Tertiary folding and thrusting in NW Svalbard. Nor: Polarinst. Rapp.ser. 46, 17-20.

Ohta. Y. \& Dallmann, W. K. (eds.) 1998: Geological map of Svalbard 1:100,000, 812G. Torellbreen. Nor. Polarinst. Temakart 29.

Orvin. A. K. 1934: Geology of the Kings Bay region, Spitsbergen. Skrifter om Svalbard og Ishavet 57. Norwegian Polar Institute.

Piepjohn, K., Thiedig. F. \& Manby, G. M. in press: Nappestacking in the Brøggerhalvoya. Geologisches Jahrbuch.

Saalmann, K. 1999: Kinematik des teriären Deckenbaus im West-Spitzbergen Falten- und Überschiebungsgürtel. (Kinematics of Tertiary nappe structures in the west Spitsbergen fault and thrust belt.) PhD thesis. Geologisch-Paläontologisches Institut, Westfälische Wilhelms Universität.

Saalmann, K. \& Brommer, A. 1997: Stratigraphy and structural evolution of eastern Broggerhalvøya, NW Spitsbergen Minst. Forsch. Geol. Paliontologie Hf. 82, 147-164.

Saalmann, K., Piepjohn. K. \& Thiedig, F. 1997: Involviering des Tertiärs von Ny-Ålesund in den alpidischen Deckenbau der Brøggerhalvøya. NW Spitsbergen. (Involvement of the NyAlesund Tertiary strata in the alpine nappe structure of Brøggerhalvøya.) Münst. Forsch. Geol. Paläontologie Hf. 82 , 129-145.

Waddams, P. 1983: The Late Precambrian succession in northwest Oscar II Land, Spitsbergen. Geol. Mag. 120. 233-252.

Welbon, A. L. \& Maher, H. D., Jr. 1992: Tertiary tectonism and basin inversion of the St. Jonsfjorden region, Svalbard. $J$. Struct. Geol. 14(1), 41-55.

Winsnes, T. S. \& Ohta. Y. 1988: Fold structures of Carboniferous to Triassic rocks in the inner part of $\mathrm{St}$. Jonsfjorden. Nor. Polarinst. Rapp.ser. 46, 21-24. 